\title{
An Accidental Teacher: Anthony Walsh and the Aboriginal Day Schools at Six Mile Creek and Inkameep, British Columbia, 1929-1942
}

\author{
Thomas Fleming, Lisa Smith, and Helen Raptis
}

\begin{abstract}
Between the two World Wars, British Columbia was home to some 49 day schools for Aboriginal children, each averaging a population of about 16 students scattered across grades one to eight. By the early 1930s, some 825 youngsters were attending such schools. Little historical attention, however, has been directed toward the operations of Indian day schools, although a large literature has otherwise documented the devastating effects of the residential schools.
\end{abstract}

A rich body of official correspondence and other sources describing the experiences of Anthony Walsh, a free spirited Irish war veteran who taught at Six Mile Creek and Inkameep day schools from the late 1920s to the early 1940s, presents an opportunity to examine the bureaucratic system that governed the day schools, the relationships that existed between agencies of church and state, not to mention the general myopia of the Department of Indian Affairs and religious authorities to the harsh realities of life on the reserves. Archival sources likewise disclose Walsh's considerable success both as a teacher and promoter of Aboriginal arts and crafts during the interwar years, as well as Walsh's role in a wider cultural movement that aimed at challenging government's social and educational policies for Aboriginal peoples. Although not immediately effective in changing the status quo, Walsh and his colleagues played an important part in sensitizing British Columbians and other Canadians to the value of Aboriginal art and culture in national life.

\section{RÉSUMÉ}

Durant l'entre-deux-guerres, la Colombie britannique hébergea jusqu’à 49 écoles de jour destinées aux enfants autochtones, chaque école comptant en moyenne 16 élèves répartis de la 1re à la 8 e année. Au début des années 1930, quelque 825 jeunes fréquentaient de telles écoles. Cependant, l'historiographie a fait peu de cas du fonctionnement des écoles de jour amérindiennes même si les effets dévastateurs des internats ont été largement étudiés.

Une abondante correspondance officielle et d'autres sources décrivent les expériences d'Anthony Walsh, un ancien combattant irlandais au fougueux caractère, qui enseigna dans les écoles de jour de Six Mile Creek et d'Inkameep depuis la fin des années 1920 jusqu’au début des années 1940. 
Elles fournissent l'occasion d'analyser le système bureaucratique qui régissait ces écoles, les relations qui existaient entre l'État et l'Église, sans oublier la myopie habituelle du ministère des Affaires indiennes et des autorités religieuses à l'égard des dures réalités de la vie dans les réserves. Les documents d'archives révèlent également le succès considérable de Walsh en tant qu'enseignant et promoteur des arts et métiers autochtones durant l'entre-deux-guerres. Elles montrent aussi le rôle que joua Walsh dans un mouvement culturel plus large qui visait à remettre en question les politiques sociales et éducatives à l'égard des autochtones. Même s'ils ne parvinrent pas à modifier rapidement la situation existante, Walsh et ses collègues contribuèrent largement à sensibiliser la population de Colombie britannique à l'importance de l'art et de la culture autochtone dans la vie nationale.

On October 23, 1989, Ernest Joseph Anthony Walsh was appointed Member of the Order of Canada for his work as the founder of Benedict Labre House, shelter for aged and homeless men in Montreal. The Order of Canada was but one of a long list of honours Walsh earned for his social service. None of these awards, all presented in Eastern Canada for his tireless humanitarian efforts, acknowledged Walsh's earlier and, arguably, most profound work teaching the indigenous peoples of British Columbia during the depression decade and after.

The purpose of this investigation is to explore Walsh's earlier experiences as a teacher in the Okanagan day schools at Six Mile Creek and Inkameep, near Oliver at the southern end of the Okanagan Valley, between 1929 and 1942. Here Walsh attempted to create a place for indigenous knowledge in school, to promote Aboriginal culture outside the classroom and to bring public attention to some of Canada's finest Aboriginal artists of the interwar era. More specifically, this paper examines Walsh's background, his educational and social ideas and the pedagogy he employed with Aboriginal youngsters in ways considered uncommon at the time. Amid an otherwise tragic history of Aboriginal education in Canada, a history marked all too frequently by neglect, abuse, inequality and shattered lives and cultures, Walsh's work in Aboriginal education represents a point of light that warrants better understanding. ${ }^{1}$ Who was Anthony

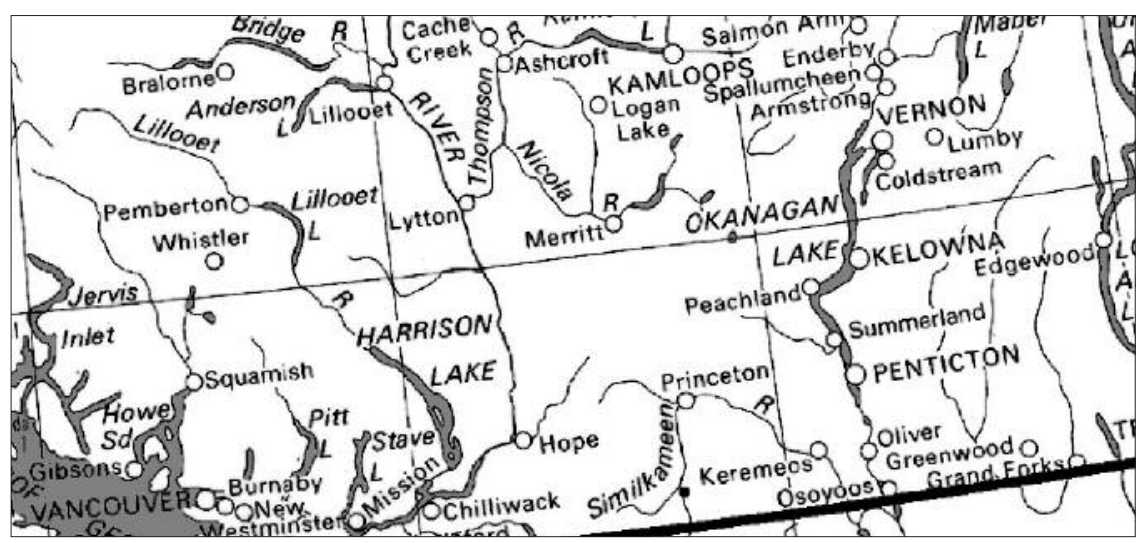

Walsh's first school in the Okanagan Valley was located at Six-Mile Creek on Bonneau Road off Westside Road in Vernon. His second school was at Inkameep, approximately 11 kilometers south of Oliver (a little less than halfway between Oliver and Osoyoos). 
Walsh? How did he become a teacher? What were the challenges he faced teaching Indian children in rural British Columbia? How did he overcome these challenges in and outside the classroom? And what, if any, kind of educational legacy did he leave? These are the principal questions guiding this study. ${ }^{2}$

\section{Background}

Little is known about Walsh's early years or his family history. What is known is that he was born in 1898 in Paris, France, to an Irish-Catholic family headed by Joseph and Lucy Walsh. ${ }^{3}$ His father trained horses for the landed gentry in Great Britain and Europe, a vocation requiring extensive travel. By all accounts, Joseph Walsh was a stern character that disciplined his children with a severity similar to that imposed on the horses he schooled. Much of Walsh's childhood was a vagabond affair spent traveling with his parents and sister, Annie, throughout Ireland, England, Scotland, Wales and France, wherever the bloodstock trade took them. By all accounts, Walsh's childhood was pastoral and unregulated by formal schooling. It is likely that he and his sister both learned to read and write under their mother's tutelage in a Rousseau-like setting free of the harsh restraints imposed by Edwardian era schools. His aunt, Agnes Walsh, predicted that he "would become a priest or a doctor" ${ }^{4}$ and nurtured the "gentle and somewhat delicate" boy who was more interested in helpless, injured animals than fine thoroughbreds." ${ }^{5}$ Of his carefree young days, Walsh fondly recalled: "I was given a very unusual opportunity of sharing for a time the lives lived by shepherds, crofters, fishermen, grooms and fishwives - people who were illiterate but poets at heart . . They were my tutors who opened a life to me that is unknown to most people."6

The adventurous side of Walsh's nature expressed itself vigorously during a 1914 family vacation in Wales when he ran away to join a Scottish regiment as a drummer boy, a brief adventure that ended with his recapture a few weeks later. ${ }^{7}$ Two years later, however, under the assumed name of "Tommy," Walsh again left home and joined the Irish Guards at the age of 18. He saw service in France and Germany, where his bravery was acknowledged. A friend, Lucien Miller, later explained: "He was in the Irish Guards in the First World War and won the Military Medal, and you don't win the Military Medal without having been very gallant in action."

Following demobilization in 1919 and still recovering from the trauma of war, Walsh found work on a large cattle farm for more than a year before attending Reading University near London as an agricultural student. In 1923, he immigrated to Canada, crossing the country from St. John's, New Brunswick, his ship's port of entry, to Alberta, where he worked on the Garland Ranch near Drumheller. Within a month, he suffered frostbite that resulted in a partial amputation of one foot. Walsh left the ranch after two years, seeking work in Edmonton and, later, in British Columbia's Okanagan Valley, where the climate was less severe. Here he turned his hand to a series of jobs that included berry picking, cooking, clerking and working in the lumber industry.

Walsh was looking for work in autumn 1929 when a Catholic missionary he had met, Father Aelred Carlyle, an English Benedictine at Bear Creek nine kilometers west of Kelowna, wrote asking him to take on a short-term teaching assignment at the Okanagan Day School for Aboriginal students at Six Mile Creek, on the outskirts of 
Vernon, at the northern end of Okanagan Lake. Carlyle indicated in his letter that the school required a substitute teacher until a replacement for the former teacher could be found. Although Walsh had no teaching experience, he was interested and could offer some reasonable educational and social credentials. After all, he was a decorated war veteran, a man of the world, single and unfettered by family responsibilities and, most significantly, a Roman Catholic who might be capable of teaching the catechism with the fervor that characterized the Irish branch of the faith. Such qualifications were obviously sufficient for the priest and Walsh was hired, expecting to serve for no more than six weeks. Exactly what prompted Walsh to abandon agricultural work in favour of teaching is not known, but it is likely that Walsh, along with tens of thousands of others, was terrified by the prospect of unemployment. Jobs were not always plentiful in rural British Columbia in the 1920s and Walsh was likely looking for employment that would tide him over, at least in the short run. Jean Webber, a friend for over 40 years, suggests that Walsh may have been moved to work with Aboriginal peoples because of a social conscience developed as a result of his association with Ireland's working poor. ${ }^{9}$ In any event, Walsh was game to take this challenge, undeterred by his awareness that a few members of the Six Mile Aboriginal community had resisted his appointment. ${ }^{10}$ He was not to know, of course, that a six-week stint would eventually turn out to last two years.

\section{Indian Day Schools}

The day school at Six Mile Creek, like its counterpart at Inkameep, was a hybrid of two existing educational institutions - the Indian residential school and the rural school. Because of their isolated locations and small classes catering to all the grades, day schools had more in common with Canada's small and usually poor rural schools than with the larger residential schools attended by most Native youngsters where students, as the name implies, lived in residence. During the interwar period, British Columbia was home to some 49 day schools, each averaging a population of about 16 students scattered across grades one to eight. Physically, day schools were similar to the more than 700 one-room schools that dotted rural and remote parts of the province, that is to say they were usually dilapidated wooden structures with sparse furniture and even less in the way of instructional supplies, despite design specifications set out by Department of Indian Affairs' (DIA) architects and engineers. As historian Brian Titley described them: "Day schools enrolled the vast majority of children. But they suffered from irregularity of attendance and the inability to find and maintain competent teachers. Neither church nor state officials put much faith in the schools' ability to sever the children from their ancestral culture."11

Administered since Confederation by the Dominion Government, day-to-day responsibility for both residential and day school operations was delegated by the DIA to various church authorities. Government officials had historically viewed day schools as less effective institutions for Aboriginal education than residential schools. Even though they were considerably less costly, they were not a popular educational choice within government because they failed to isolate Aboriginal children from family and 
tribal influences, the so-called "downfall" of reserve life, an objective central to the policy of cultural imperialism set out by Dominion Government authorities. ${ }^{12}$ However, in the decade prior to World War II, day schools blossomed in rural areas of British Columbia where Aboriginal populations were sufficiently large to allow schools to be sited in local communities. ${ }^{13}$ By the Great Depression, day schools had grown to outnumber residential schools three to one, compelling the DIA to admit: "Day schools on reserves, where our wards are permanently settled, quite properly are becoming increasingly important." ${ }^{14}$ In fact, by the early 1930s, some 825 Aboriginal youngsters were attending day schools in British Columbia, in addition to the 1864 youngsters situated in 16 residential schools, making the province home to the largest number of Aboriginal schools and, arguably, the most ethnically diverse population of Aboriginal students across the Dominion. ${ }^{15}$

Like rural schools in general, day schools faced enormous problems in attracting and keeping qualified teachers, even in the 1930s when work was generally scarce. ${ }^{16}$ The average posting for a teacher in one of the province's hinterland districts was about 10 months. Few teachers returned to their jobs for a second year, believing that any new assignment would be better to the one they were leaving. Life was generally hard for teachers in poor districts throughout the province where isolation, loneliness and long cold winters in roughly built schools and teacherages was the order of the day. But fewer still were prepared to brave the even harsher conditions of school life on the reserves, where the culture shock and poverty of the settlements was usually more extreme, where instructional resources were in even shorter supply, and where the indifference of church and DIA officials likely surpassed that of many small public school boards. As one of Walsh's biographers, John Buell, observed: "Teaching in general was poorly paid, and a teacher was regarded as someone who couldn't do anything else. Teaching Indians was even lower on the scale."17

Such conditions meant that rural and reserve schools could attract only the youngest and most inexperienced teachers, those with marginal teaching credentials, or those with a questionable past who had fled other postings because of scandal, dereliction of duty or, in some cases, alcoholism. ${ }^{18}$ Particularly daunting was the fact that day school teachers ordinarily worked alone and were usually the only non-Aboriginals on reserves and, frequently, the only native English speakers for miles around. No less troubling was the expectation that day school teachers could somehow socialize Native students into the prevailing norms of non-Aboriginal society when the children, unlike those in residential schools, could return to their families at classes' end, speak their own language out of school and remain, for better or worse, under the influence of community elders. ${ }^{19}$

\section{An Accidental Teacher}

Like many male teachers of his generation for whom teaching was a second or, even, third career choice, Walsh's entry into the profession was accidental. And, like isolated schools across the country, the school at Six Mile Creek had suffered its own share of difficulties finding competent teachers. By 1924, the school, founded some four years earlier, was entrusted to a former architect, William Marsden, and his wife. Although 
the Marsdens remained four and a half years, their tenure was a social and educational disaster for the community and the DIA in general. Ill health was a constant problem, as was the couple's inability to maintain cordial relations with the Aboriginal community. Indian Agent Ball wrote to the DIA in August 27, 1928, claiming that Mrs. Marsden, "besides quarrelling with Indian women . . . is totally unfitted temperamentally to teach Indian children or have anything to do with the Indian people." ${ }^{20}$ Ball summed it up this way: "it was only on compassionate grounds that I did not recommend dismissal of these people some time ago." ${ }^{21}$ Following a three-month leave of absence in the spring of 1928 due to Marsden's "nervous breakdown,"22 he spent most of his summer holidays trying to recuperate in St. Paul's Hospital in Vancouver. When he finally returned to the school in August, he was unable to resume his duties and resigned his teaching position.

Marsden's successor at Six Mile was George Quigley, a seven-year classroom veteran, who seemed, at least at the outset, a reasonable candidate to R.H. Cairns, Inspector of Indian Schools. Unfortunately, Quigley's past caught up with him when Ball reported to Ottawa that a provincial warrant had been issued against Quigley for "nonmaintenance of his family," indicating that he was also suspected of orchestrating shady timber sales using trees grown on Indian land. ${ }^{23}$ When Quigley disappeared in autumn 1929, the school was once more in the market for a teacher, whereupon Carlyle approached Walsh and, soon after, secured Ball's approval to make the appointment.

When Walsh arrived at Six Mile Creek in November 1929, he found the school and teacherage abandoned. In his unpublished memoirs, Walsh described the schoolroom as "tiny" and the adjoining kitchen and bedroom as "equally small." 24 Walsh was more than a little taken aback by the challenges at hand. Not only was he to serve as the teacher of some 30 youngsters but, as the nearest doctor was 16 miles away, he was expected to dispense medicines and, as the community knew him better, to provide instructions "on the care of the sick and, of all things, the feeding of their infants." 25 Other duties, he learned also, accrued to the schoolmaster's post: "Another unexpected event happened when for a time the tribe was without a chief, so my house became at intervals a makeshift court of law. I would have to listen with gravity, to both sides of family frays, matrimonial tangles, and the inevitable problems arising from the waywardness of some of the younger men and women." ${ }^{26}$ As he recalled later, "it was only my Irish sense of humor that kept me going." 27

A bit perplexed but nonetheless undeterred by his new social responsibilities, Walsh struggled to find his feet as a teacher. Untrammeled by much in the way of pedagogical baggage, Walsh began to teach the curriculum of the day, based principally on provincial school guidelines. This consisted of reading and writing, arithmetic, English language, geography, nature study and health, along with instruction in Bible stories and catechism as befitting the school's designation as a "Catholic" institution. ${ }^{28}$ To these subjects, Walsh added two small instructional components in agriculture and art, as well as establishing an "Indian Crafts Guild" on the reserve that doubled as a "branch" of the junior Red Cross. Here, Aboriginal children learned to create art and conduct the business of the guild, as local Indian Agent James Coleman reported in "a formal and businesslike fashion with regular meetings where questions are gravely debated 
and subject to resolutions, and this without the "interference" of the teacher." ${ }^{29}$ Apart from these developments, little else is recorded about Walsh's first two years of teaching, other than the school operated in accordance with standard Indian day-school regulations: classes were held weekdays from 9 a.m. to noon, and from 1 to 4 p.m. with a recess in each session. ${ }^{30}$ Teaching sessions ran from September 1 to December 22, and from January 3 to June 30 annually. ${ }^{31}$

Despite a few community members who remained suspicious about the school's influence on Aboriginal life, Walsh was successful at Six Mile Creek. Agent Coleman, in fact, portrayed him in written reports as an exemplar for Aboriginal schools in general: "A teacher fitted for this class of work will fill the school despite opposition from any particular section of the Band and this is evidenced by the school on Okanagan Indian Reserve No.1 under the charge of Mr. Walsh ... where the opposition has been even greater [than the Penticton Indian Day School]." ${ }^{2}$ Summing up, Coleman wrote assuredly: "The strongest opponents to the school are now sending their children there." ${ }^{33}$ Such praise suggests that Walsh's first two years teaching at the Okanagan day school were rewarding and prepared him well for his later and remarkable work at Inkameep.

Although still apparently committed to teaching, Walsh requested a transfer from Six Mile Creek in 1932, claiming he was "exhausted" from shouldering the many ancillary responsibilities in the community attached to the teaching job. His request was roundly supported by District Inspector of Indian Schools, Captain Gerald Barry, who assigned Walsh the post at Inkameep Indian day school on September 1, 1932 for a salary of $\$ 81$ a month. ${ }^{34}$

\section{The Day School at Inkameep}

Although part of the Dominion Government's day school system, Inkameep was unique in two respects since its establishment in early 1916. First, the school came about solely through an Indian initiative and, as such, it was the first Indian day school so developed in the Okanagan Agency. A November 5, 1914 letter to D.C. Scott, Deputy Superintendent General in the Department of Indian Affairs, from Indian Agent Robert Brown reported that at Inkameep, Chief Baptiste had requested a school be constructed on the Osoyoos reserve, indicating also that he was willing to use the community church as a schoolhouse and, if necessary, to relocate the building to a more suitable site..$^{35}$ Second, the Inkameep community, consisting of some 70 members, appeared more independent-minded than other reserves and had vigorously expressed its opposition to any educational institution other than a day school. Inspector A. McGraw's July 21, 1919 letter to Indian Affairs in Ottawa observed that Aboriginal leaders from other villages had voted down day school proposals in the agency, but the Inkameep chief insisted on having his children educated on the reserve rather than attending a residential school. Walsh later recalled that Baptiste "was ahead of his time in that he wanted his children taught within their own background, not sent away to the residential schools." ${ }^{\text {"6 }}$ Baptiste's objective, Walsh further noted, was that "his children be equipped ... to hold their own in a white man's world." ${ }^{37}$ 
As it turned out, the school proved far from perfect in construction. Indian Affairs described it as "the merest excuse in the way of accommodation." 38 Apart from its sparse nature, no provision had been made for a teacher's living quarters, an omission noted in a 1919 letter from the Indian Agencies inspectorate that pointed out, "the teacher is living in a tent on the bank of Inkameep Creek, summer and winter." ${ }^{39}$ No doubt, the "deplorable" living conditions, to use the DIA's own description, prompted the staffing problems that interrupted the school's operations, as did the interest of Chief Baptiste in retaining control over educational affairs.

In fact, Baptiste himself hired Inkameep's first teacher, John Norwood, directly and paid his salary from funds raised by the 100 or so members who comprised the Inkameep reserve. The appointment proved short-lived. Norwood resigned in October 1916, after seven months of employment, allegedly "owing to unpleasantness with the Chief and members of the Osoyoos Band." ${ }^{\circ 0}$ According to Indian Agent Ball: "The school made a bad start by employing a negro named Norwood as its first teacher, and the children were learning English with a decidedly negro accent, but acquired nothing else in the way of education." ${ }^{41}$ Nonetheless, according to Walsh, Norwood "was the only person who was willing to take on a job in such a remote area at that time." 42

Miss Christina McLeod, formerly a teacher on the Colville reserve in northern Washington State, succeeded Norwood. Unlike Norwood, McLeod refused to billet with the Aboriginal community, opting to live year-round in a tent until she resigned in the spring of 1919, at which time the school was closed until another teacher could be found. Hiring a replacement proved difficult, but eventually the DIA recruited Miss Gertrude Hozier, formerly of Fairview near Oliver, British Columbia. Equipped with a high school certificate, a substantial credential held by only a small number of provincial teachers at the time, Hozier was officially deemed "well qualified to teach this school which only had primary courses." ${ }^{43}$ Under Hozier's care, the school was reopened in December 1919 after a six-month hiatus. Hozier remained until 1923 when Miss H.E. McDonald took the position. That same year, the Annual Report of the Department of Indian Affairs declared the school's religious affiliation as Roman Catholic. McDonald stayed four years before turning over the teaching chores to a Miss M. Waddell in 1927. Waddell's tenure lasted only a year until F.G.M. Grist, a male teacher, was appointed in 1928 following his brief sojourn at Six Mile Creek. Grist, originally a specialist in agriculture and stock management who had later turned his hand to teaching, remained at Inkameep for four years until 1932, when he transferred to the day school at Shalalth, and Walsh took his place.

Otherwise, the Inkameep Indian Day School was in many ways like any other reserve or small rural school in that it provided instruction across the elementary grades for some 9 to 12 children daily, sometimes swelling to as many as $18 .{ }^{44}$ Until 1933 , however, no pupil had advanced beyond grade 5 and pupil attendance was sporadic at best. ${ }^{45}$ Moreover, like most other reserve schools, students did not speak English as their first language, nor did their parents automatically value the education the schools imparted. In fact, none of Walsh's students could speak English at the time of his arrival and, initially, Inkameep band members were more than a little uncomfortable with Walsh's presence and wary about the schooling he would provide. 


\section{Teaching as Cultural Appreciation}

Walsh came to Inkameep a little tired but enriched from his experiences at Six Mile Creek. Although lacking whatever measures of pedagogical tradecraft that normal school instructors dispensed to the graduates of the two provincial teacher training institutions in Vancouver and Victoria, Walsh was blessed by a number of personal attributes and life skills that would serve him well at Inkameep. Walsh was patient and immensely observant. Military service had taught him to be resourceful as well as disciplined and, in addition, to be flexible enough to solve problems as they appeared. His own scholastic upbringing had been unconventional to say the least. Save for the army and a short sojourn at university, he was a stranger to institutional life and the standardized behaviours institutions sought to impose. Growing up without the discipline, order, and routine characteristic of schools still imprisoned by Victorian structures, Walsh was long accustomed to a free, self-directed and holistic approach to learning constrained by neither teacher nor text. His own gentle and sensitive nature had been guided largely by his general educational interests and by a process mainly consisting of learning by doing, and by watching others undertake tasks.

Walsh's childhood was advantaged in another respect. Travel with his family had exposed him to the folkways of different cultures and occupations, mostly traditionbound and rural. Here he had learned to pay attention to the subtleties and customs of groups and individuals removed from the social conventions regulating middle-class Edwardian society. Walsh's quiet disposition and non-authoritarian manner had served him well among the Aboriginal community at Six Mile Creek, allowing him to learn the rudiments of one Indian culture and to appreciate the rituals punctuating life on the reserve. Six Mile Creek reinforced Walsh's interest in other cultures and squared well with his emerging interest in the history of the Okanagan Valley and the traditions of the Native people who first settled the region. His appreciation of other cultures and other ways of living had already proved an essential element of working successfully with Aboriginal children, as well as with a larger Aboriginal community. Unmoved by the social distinctions made by others, the independent-minded Walsh had learned first-hand that "these Indian children were a creative and talented people. They were not dirty and decadent as a certain number of White neighbours thought." ${ }^{46}$ Jean Webber, a longtime friend, traced Walsh's cultural sensitivity to his childhood in Ireland and to his distaste for Britain's "suppression of an indigenous culture in Ireland," a tyranny witnessed first hand. ${ }^{47}$

Although uncertified as a teacher, Walsh was likely better educated, broadly speaking, than many of his contemporaries in elementary classrooms, most of who could boast of little more than a year's teacher training beyond junior matriculation [roughly the completion of grade 11 today]. He had traveled widely, attended university, distinguished himself in Europe's trenches and had worked in a variety of jobs during his odyssey across Canada. He was also unusual in another respect: he was entirely comfortable with his own solitude, something not always found in early twentieth century teachers, many of whom despaired of the geographic and social isolation that commonly marked rural life, as various British Columbia historians have shown. ${ }^{48}$ Toward 
the end of the war, Walsh would matter-of-factly remark that he never made any Indian friends at Inkameep and that his relationship with the community was strictly confined to his role as teacher. As Buell later explained: "He was not a-social or anti-social, he was just solitary, not part of any milieu. He had been that way since boyhood." ${ }^{4}$

Understandably, his background and attitude helped forge a teacher of some considerable maturity and perspective, someone less concerned with subject mastery than with the vitality of experience that resulted when a student's own curiosity or interest led them to the acquisition of new knowledge and skills. This developmental and, arguably, unstructured outlook toward learning probably made Walsh more similar to some of the idiosyncratic characters who staffed the small private schools catering to the children of the province's elite than to the great majority of public school teachers strongly conditioned in the normal schools to believe that deviation from lesson plans, rote methods of learning, and other pedagogical prescriptions constituted grave professional sins, especially in the eyes of the school inspectors who gauged their proficiency.

As in the case of most lives in classrooms from the late-nineteenth century to the mid-twentieth century, few recorded observations of Walsh's teaching remain. Nevertheless, evidence that exists suggests that Walsh's approach was an amalgam of both traditional and progressive methods. Some aspects of Walsh's teaching certainly mirrored conventional school practices of the time notably, as students would later recall, his strict insistence on classroom order and control..$^{50}$ But apart from the necessities of managing a class of youngsters from 7 to 16, with a couple of four year-olds occasionally in attendance, Walsh's approach in other respects differed markedly from the instructional mainstream. For one thing, unlike many individuals who taught Aboriginal children, Walsh held an unusually enlightened view about the potential of Aboriginal people and their importance to Canada's cultural heritage. "Canadian Indians are a creative and artistic people," Walsh declared. "They possess a wealth of common sense, intelligence and integrity." Their marginalization, he concluded with a view rarely shared at the time, "discredits the nation." 51

Walsh's accomplishments were modest during his first two years at Inkameep. For reasons historical and otherwise, Walsh's principal challenge was overcoming the suspicion that surrounded all outsiders. In several instances, he later remarked, it took about two years for the children to begin feeling comfortable with him. As he explained: "Generally the Indian adults assumed, and with them their children, that no matter how kind a White man might seem, he was always suspect." ${ }^{2}$ Walsh easily rationalized this attitude as one "largely due to the many broken promises of the past, and the greed and disdain of Whites. .." In accordance with such sentiments, Walsh moved slowly in establishing relationships with the children and community at Inkameep: "I . . . treated the new pupils with much care." He later recounted: "I listened and tried to meet them half way. They came to sense this and as they felt secure they started to talk and opened up like flowers after spring rains." Reflecting on the "rich creativity" he found among the youngsters, he observed: "Had I the energy or the ability at that time to have written about what the Indian children had to say, I could have written a classic in early childhood education." 53 


\section{A New Curricular Emphasis}

Walsh's instructional strategy really began to take shape during the 1935-1936 school year, largely the result of three separate and serendipitous events that had occurred during his time as a teacher. As Walsh later recalled:

Once I tried to illustrate a point by drawing on the blackboard, and they howled with ridicule at my clumsiness. I invited volunteers to come forward to show what they could do. Their originality was startling. 'You see,' I pointed out, 'how much better you can draw than the white man!' From then on I encouraged them to express themselves wherever possible through drawing. ${ }^{54}$

Walsh's idea to involve students in art was reinforced by a second development, notably his own deepening appreciation of the Okanagan landscape and the subtle imprints of earlier Aboriginal peoples:

One day, while hiking through the surrounding hills, I came upon some pictographs that had withstood countless summer suns and winter blizzards. These crude illustrations depicted a hunter shooting a deer, a fish, a few birds, some stars and a sun. Then the idea came in a flash - I'd attempt to bring about an improvement in racial relationships through the medium of art. ${ }^{55}$

Within months, Walsh made art a mainstay of the everyday curriculum, viewing it increasingly as a pathway to all manner of learning and, more importantly, a royal road that children could travel in search of their own cultural pride. Youngsters warmed immediately to exercises in drawing and parents and other community members began to encourage children's efforts by explaining the meaning of songs, legends, as well as various rituals and symbols.

Art as a medium of learning also afforded Walsh a new and broader grammar to bridge the differences between the spiritual traditions of the Okanagan Indians and the spiritual elements of Catholicism embodied in the catechism he taught, which continued to grip him personally. ${ }^{56}$ This new emphasis on the visual arts, however, was impossible to accommodate within an already crowded pedagogical space and, as a result, Walsh was obliged to lengthen the school day by one hour, which he did with the approval of students and their families.

The benefits of Walsh's cultural studies became apparent a year later as a third event unfolded. In preparation for a Christmas concert, Walsh asked the class to draw the Nativity scene, imagining that the setting was the Okanagan Valley instead of Bethlehem. The youngsters depicted Mary wearing buckskin and a papoose board with local animals attending the infant Jesus. A teepee stood in place of the inn and no manger was evident. Most remarkable among the art work was that of Francis Baptiste, "who until then had not shown much talent for drawing." ${ }^{57}$ Baptiste had outlined the entire Nativity scene over much of the blackboard, a scene he would later commit to buckskin in the schoolhouse garage. So successful were these activities that the children asked to be allowed to make and sell Christmas cards based on their sketches as a way of funding 
the purchase of supplies for other art projects. ${ }^{58}$ Walsh agreed to have the drawings printed on Christmas cards and posted to friends in Oliver and elsewhere.

The Nativity exercises marked a turning point in Walsh's teaching career and, indeed, in the broader artistic development of the Inkameep students. From these sketches, one student, Francis Baptiste (Sis-hu-lk in the language of his own people) designed a large deerskin painting that was sent to the Royal Drawing Society in London, an institution that hosted an annual children's art competition throughout the Commonwealth. Baptiste's submission was made possible through the intervention of one of Walsh's friends, Dorothy Alison, a recipient of one of the 1935 Christmas cards. ${ }^{59}$ After viewing the children's drawings, she sent a sample to Adrian Stokes, her uncle and well-known English painter and art critic who, in turn, passed it on to his colleague, the renowned British equestrian artist, Sir Alfred Munnings.

Baptiste's painting, "Indian Boys in Training" was awarded the Bronze Star by the Royal Drawing Society in 1936, making him the first Canadian to earn such international distinction in a competition consisting of some 6,000 entries. ${ }^{60}$ Soon after, the Society would purchase this painting to add to its permanent collection. In 1937, Baptiste won the Silver Star for his painting, "St. Francis Feeding the Birds." Drawings by other students, notably Johnnie Stelkia, earned two Bronze Stars. ${ }^{61}$ Altogether, these honours greatly improved Walsh's credibility with the community elders at Inkameep and his reputation as a teacher. "When mention of the award was carried in Canadian newspapers and the news reached the Reserve," he later wrote, "there was much rejoicing. A few of the older Okanagan people who formerly had been very reticent now came forward and offered valuable information about the customs of their forebears." 62 As Walsh later reported: "Compositions, which had always been unpopular, became acceptable when brightened by the addition of pen and ink sketches. Table and health rules were more easily remembered when they were illustrated by birds and animals clad in gay and fantastic human attire." 63

To promote the work of his young protégés, Walsh assembled another collection of six large studies tracing the changes in Aboriginal life "since the arrival of the white man" that he took to be exhibited at galleries in London, Paris, Dublin and at the Glasgow Fair in summer 1938. ${ }^{64}$ Later that year, the Canadian Junior Red Cross organized a second European exhibition of these works. Walsh enjoyed a reasonably long association with this organization dating back to Six Mile Creek where he had established a junior chapter to raise children's awareness about health and nutrition and to acquaint them with the business side of producing Indian crafts. ${ }^{65} \mathrm{~A} 1939$ article in the Education Digest records the success of these exhibitions, noting that, in addition to a silver medal "from the Guild Hall in London," the Inkameep children had earned additional "certificates from Paris, Vienna, and Leland Stanford [Leland Stanford Jr. University, Palo Alto, California]."66

The Christmas drawings also led to publication of a small illustrated booklet, The Tale of the Nativity, which recounted the Nativity through the eyes of an Okanagan child and which was, again, sold to raise funds for the children's art supplies. The November 1941 issue of the B.C. Teacher, a professional magazine for provincial teachers, featured Mary Elizabeth Coleman's laudatory review of the booklet and Walsh's 
efforts: "British Columbia, and indeed all of Canada, is the richer for the devoted work of this gifted man, Anthony Walsh, who has recognized and encouraged the talents of his pupils without attempting to Anglicize them." ${ }^{.67}$

Drawing, although now a central element in children's learning was not the only form of visual art Walsh introduced. To foster greater student interest and demonstrate the interconnectedness of knowledge, Walsh experimented with other types of artistic expression and, with the help of parents and community members, began providing opportunities for loom making and weaving, sculpting using local clay and papier maché, carving figures and masks in wood, and costume making using buckskin and flannel. ${ }^{68}$ The schoolroom's inadequacy for such purposes caused Walsh to convert the lean-to structure attached to the school from a stable into a studio. Along with the paucity of facilities, a general shortage of supplies, characteristic of rural life in the Depression, posed persistent problems for the art program. Nevertheless, Walsh and the Aboriginal community proved resourceful by making paints and fabric dyes using ancient techniques and by substituting materials such as cheesecloth for buckskin costumes and papier maché for wood in the design of masks.

As part of his cultural recovery initiative, Walsh also introduced music and dramatic arts to enhance the curriculum. Walsh had listened to folkloric songs sung by Native wranglers on solitary rides through the reserve and wanted children to learn these songs in their own language. Attempts to encourage them in this regard came to no avail until he orchestrated a competition to see who could learn the most songs. Motivated by no more than the prize of a brightly coloured English postcard, students quickly sought the assistance of parents and grandparents, a development that led Walsh eventually to catalogue more than 40 traditional songs. Learning about their own musical past also changed children's classroom behaviour, sometimes with humorous effects. Singing proved so popular that children broke into song on every possible occasion, obliging Walsh to dampen their enthusiasm so that regular instruction could continue. ${ }^{69}$

To improve student self-confidence in conversational English, Walsh also introduced a daily "radio show" to the classroom in which students were asked to make school announcements on station "INK." The seven-minute-a-day radio show, he believed, gave them additional opportunities to practice speaking English in front of an audience and to develop poise and confidence while speaking publicly. "More than anything else," Walsh claimed, "participation in the INK helped children to gain confidence and discover themselves."

Dramatic arts were added in November 1938 when Walsh recruited two older "white" students from Oliver, Elizabeth Renji and Isabel Christie, to assist him in creating small plays, later known as The Inkameep Tales, for the children, based on Okanagan legends. ${ }^{71}$ Some plays, such as "Why the Ant's Waist is Small" and "Why the Chipmunk's Coat is Striped," were titled to reflect a particular moral lesson. Once children grew accustomed to performing these plays, Walsh allowed them to develop their own dramatic works and to determine "by secret ballot" which students "gave the most realistic portrayals" and should, therefore, appear in community performances. As in other aspects of his teaching, Walsh demonstrated a general trust in the children and their capacity to withstand disappointment and make difficult decisions. 
"[S]addling the children with the additional responsibility of delegating parts involved risks," Walsh observed. "[B] ut they were worth taking, for they grew in their own selfesteem and in developing critical standards." 72

Looking back at a community performance of The Inkameep Tales, Walsh recalled: "I asked the old people to come and a few whites. Something was born anew in the eyes of the Indian elders as they saw the fervor and skill of their children." 73 This new attention to traditional Okanagan culture did not go unnoticed in the national newspapers, The Family Herald and Weekly Star, which reported the cooperative character of learning at Inkameep and Walsh's dexterity in engaging the entire Aboriginal community: "The children learn these [legends] from their parents, who search their memories for old songs and stories told them in the past. They bring their findings to their teacher who makes a record of them and dramatizes the legends for presentation by the children."74

Other honours followed. In April 1940, Major Llewellyn Bullock-Webster, the provincial education department's director of community drama, presented the Inkameep students with the Oskenonton Cup, a provincial award "given to the Indian drama group doing the most artistic work" for their interpretation of Okanagan legends. ${ }^{75}$ The following year, 1941, Walsh and six of the Inkameep students were invited to Victoria to perform three short plays as part of the festivities to open Thunderbird Park, a park built as a tribute to the totemic arts and crafts of Aboriginal peoples. Following this performance, the children were invited to perform live on CBC radio in Vancouver.

News of Inkameep continued to spread along with other awards and acknowledgments. In 1943, the Inkameep students earned first-place for their submission at the Canadian Handicrafts Guild. Prominent academics, too, voiced approval. In 1940, noted Canadian educational progressive, Peter Sandiford of the Ontario College of Education, helped spread the "gospel of Inkameep" through mention of Walsh's work in The School, the leading educational journal he edited. ${ }^{76}$ Librarian Anne Eaton, of New York's Lincoln School of Teachers, requested permission to reprint "Tale of the Nativity" for a Viking Press anthology to be used as a school textbook. ${ }^{77}$ Kenneth Kidd and Donald Cameron, officials at the Royal Ontario Museum and the University of Alberta, respectively, also paid tribute to Walsh's success at Inkameep, ${ }^{78}$ and Vancouver educator, Norman Black, the progressive-minded editor of the B.C. Teacher, read by two-thirds of British Columbia's teachers, was featuring articles advising "the salvaging of our Indian tribes calls for measures that will restore their self-respect and that will stir them to the utilization of their own resources." 79

Publicity surrounding the Royal Drawing Society's competition in London, however, reconfigured the social landscape of Walsh's life and, in so doing, removed much of the privacy he had long sought and enjoyed. The press - local, regional, and national - had discovered Walsh and had begun to lionize him for his success. ${ }^{80}$ Banner lines now proclaimed "Indian School Produces More Work Worth of Highest Merit," "Inkameep is a Monument to One Man," "Schoolmaster Revives Pride of Race Among Talented Indians Near Oliver," "BC's Ancient Indian Songs to be Revived," and "He Works to Restore Indian Pride of Race." ${ }^{81}$ 


\section{Leaving Inkameep}

In his 1969 volume, Tragedy is Not Enough, existential philosopher Karl Jaspers observed that "true tragedy" can only grow out of "true success." 82 And so it was with Walsh. After a decade of difficult but fulfilling work that had earned him national and international recognition for teaching, Walsh found himself tired and discontented with life at Inkameep. The heightened publicity now surrounding his introduction of creative arts to the curriculum seemed only to drive him farther from his original work with the children. ${ }^{83}$ In abrupt fashion, he tendered his resignation to Indian Agent A.H. Barber: "I am writing to inform you that I am resigning from the post of teacher at the Inkameep Day School at the end of December 1942." He went on to explain the reason for his resignation: "I expect to take a position with the Canadian Legion War Services early in 1943. After a short training, I am hoping to proceed overseas." ${ }^{84}$ What actually prompted Walsh's resignation in 1942 remains a matter of conjecture. Decades later he confided that his resignation was associated with the paternalism that accompanied a change of band leadership adding, simply, "it was time to leave." ${ }^{85}$ Amateur ethnographer and the drive-force behind the Society for the Furtherance of British Columbia Indian Arts and Crafts, Alice Ravenhill, observed otherwise: "Parents began to withdraw their children from the school to send them off the reservation to residential schools claiming the curriculum was unbalanced." $\$ 6$

Ravenhill's view was shared by Indian agent and one-time Walsh admirer, James Coleman, who reported to headquarters: "Eventually the increasingly unbalanced curriculum at the Indian school overtook him and some of the parents transferred their children to Cranbrook Indian Residential School in the East Kootenays, complaining that they were receiving no worthwhile education under Mr. Walsh." ${ }^{87}$ To this, Coleman dismissively added: "Mr. Walsh had not professional qualifications and no great ability as a teacher but. . had quite an appeal with the local uninformed intelligentsia." 88 Obviously, Coleman had set aside earlier commendations of Walsh that reached back to his first year at Six Mile Creek, particularly the congratulations he had extended to Walsh "for his keen interest in the children's work, and sacrifice of a good deal of his spare time to the development of this talent in his pupils." Similarly, Coleman had ignored what he had earlier written about the positive effects of Walsh's instruction: "Practically all of the children of this school turn out excellent artwork and would quite easily develop work of commercial value." ${ }^{99}$

Whether Walsh's resignation was prompted by the dissatisfaction of the Inkameep community with his educational program, or whether it was driven by his own sense that it was time to close this chapter in his life, remains unclear. In any event, local relationships were patched up to the point where Aboriginal elders were pleased to attend a farewell dinner in his honour held by his friends in Oliver. ${ }^{90}$ Decades after, Walsh described the evening: "In my own talk," he looked back, "I said there was an unsung song in my heart. . .for the people of Inkameep." ${ }^{11}$ But, from other recollections, there is a sense that his heart was divided and that he was haunted by how his decision to leave had been perceived. "The general reaction of my friends about my decision to leave Inkameep and join the Legion War Services," he recalled later, "was that I had let them down." ${ }^{92}$ 
Interestingly enough, neither DIA officials nor their policies seem to have contributed much to Walsh's decision. Looking back, Walsh suggested, the three government officials who supervised him at Inkameep, presented no particular problems. Walsh categorized the first of the three agents as "not very sympathetic and. . .rather tough." ${ }^{33}$ As Walsh explained: "His concern was the three R's, and he did not recognize the creative work that was going on." ${ }^{4}$ The second government administrator, according to Walsh "was a first-class man, but all the odds were against him. He was dedicated and concerned, but the Indians misunderstood him and did not realize that he had to deal with the bureaucracy of the Department of Indian Affairs." 95 Finally, Walsh recorded: "When the third man came, he just left me entirely alone. I just plunged ahead and did things." Notwithstanding officialdom's lack of impact on his own work, Walsh never forgot that the negative attitude sometimes shown by Aboriginal children toward learning, especially their reluctance to embrace an alien curriculum they scarcely understood, was attributable to "the repression exercised by government officials who thought it desirable to bring about a complete break with the past."

The vacancy left by Walsh proved difficult for the DIA to fill. Not sharing Walsh's proclivity for an ascetic lifestyle, teachers who followed him found it difficult to survive, much less thrive, under such conditions. While Walsh roamed New Mexico studying various tribes, Inkameep re-opened in September 1943 with the appointment of P.J. Kiernan who was, like Walsh "not a British subject. . . [but] a citizen of the Irish Free State." ${ }^{88}$ Nevertheless, Indian agent Alfred Barber seemed optimistic at the time, writing: "The Indians are pleased to have the school re-opened and I think Mr. Kiernan will probably get along well." ${ }^{99}$ By January 1944, little more than three months later, Barber's tone was markedly different. Suddenly he found Kiernan, who had just submitted his resignation, to be a chronic complainer and "totally out of his element in this school." 100 It seems the new teacher was unwilling to endure the impoverished living conditions that Walsh had not even deemed worthy of mention, much less protest, including a lack of furniture and bedding, a rotting mattress, dangerous cook-stove and a door so worn that "the snow blows through the gap." ${ }^{101}$ In a letter to Major D.M. MacKay, Indian Commissioner for B.C., the DIA's Superintendent of Welfare and Training, R.A. Hoey, finally put the matter of teacher's living conditions at Inkameep forthrightly: "Being familiar with these quarters, I must admit it is difficult to understand how the Indian Affairs Branch can expect a qualified teacher, who has perforce to spend so much of his time away on a reserve, to live in such very primitive conditions as those existing at Inkameep." ${ }^{102}$

Even with renovations in 1945 to "recondition and enlarge the teacher quarters," no suitable person could be found for some time. Eventually, the position was filled by a Catholic lay missionary who, by all accounts, set out to purge the school of Walsh's instructional legacy. Former student Irene Baptiste recalled: "He said the masks were the work of demons. . . He took every one we ever had and destroyed them. . . He tried to make us ashamed that we were Indian. . . He thought we were just garbage. He used to stand there with a great big ruler and just scare us half to death all day long. I think that's why most kids quit school, like me." ${ }^{103}$ Lucien Miller, one of Walsh's biographers, was likewise shocked to learn that two white men, a Catholic layman and a priest, threw out everything Tony had accomplished, destroying the artifacts of the 
Okanagan renaissance. ${ }^{104}$ Dr. Campbell-Brown, a Quaker and Vernon-based pediatrician who had known Walsh well, assessed the school after Walsh's departure in terms no less bleak: "During a recent trip in the Interior, I stopped at Oliver and made inquiries about Mr. Walsh. They said he had left there years ago, and when he departed his most promising pupils let their studies slide, and re-dedicated their lives to such pursuits as shooting pool." 105

Sadly, Walsh's life during the remainder of the 1940s assumed a somewhat aimless and itinerant character as he moved about frequently to accommodate his interests and opportunities he found. For the most part, he continued to study and promote Aboriginal arts and crafts and to instruct white society on the value of greater cultural sensitivity toward Indians and their need for greater social justice. Even his war work as an occupational therapist with the Legion's War Services camps in Port Alberni and Gordon Head outside Victoria did not prevent him from such activities. Nevertheless, after the war, his efforts to promote Aboriginal culture became less focused and certainly less effective than during his time at Inkameep. As part of eking out a living, and a poor living at that, he gave occasional lectures across the country or performed "oneman shows" celebrating dances he had learned at Inkameep.

After 1945, Walsh traveled when he could, sometimes to San Francisco, sometimes to Arizona and New Mexico. ${ }^{106}$ During the postwar years, he also published several articles on the history of Native peoples and on his experience teaching. He also coauthored (with Lytton residential school teacher Noel Stewart) a brief submitted to the Dominion Government that advised reforms to the official treatment of Indians. ${ }^{107}$ In 1947, he was unsuccessful in persuading Maclean's magazine to purchase the "Tale of the Nativity." ${ }^{108}$ In 1949, he "burnt his bridges behind him out West," in Miller's words, and moved to Montreal where he struggled as an actor performing Okanagan songs and dances in public concerts and presented a CBC radio play. ${ }^{109}$

Moving eastward ushered a new and productive chapter in Walsh's life. For the next quarter of a century, Walsh devoted himself tirelessly to the cause of social justice and, most notably, to the care of aged and homeless men in Montreal. His efforts in establishing the Benedict Labre shelter would lead to national recognition as a great humanitarian. In 1975, Concordia University awarded Walsh a Doctor of Laws honoris causa for his "love and concern for his fellow human beings," the first in a long list of academic and other public honours he earned for a selfless dedication to others. Largely forgotten in this acclaim was his work as a teacher in British Columbia. Save for 1964, when the province's Lieutenant Governor, G.R. Pearkes, honoured Walsh for "years of service to the Native People of British Columbia," his work at Six Mile Creek and Inkameep was essentially forgotten. ${ }^{110}$ Even Canada Council did not deem his memoirs as a teacher sufficiently important to warrant a publication-support grant. ${ }^{111}$

\section{A Teacher's Legacy}

Anthony Walsh's experiences at Six Mile Creek and Inkameep help illuminate British Columbia's social and educational history in several ways. First, Walsh's story augments a remarkably small historical literature on the lives and pedagogy of teachers in small communities. In more than a decade of teaching in two small communities, a mark of 
considerable longevity by standards of the day, Walsh honed his classroom skills and became a secular pastor to a small number of Aboriginal children. The pastoral responsibility he learned among the communities on these two isolated reserves forever changed his life and became the benchmark against which the entire life of this complex and solitary individual was later measured. As he later remarked: "The life I spent at Inkameep with its solitude was a kind of novitiate which enabled me to think through basic things, and it prepared me for the work with outcasts. . in Montreal."112

Ancient in his wisdom about what really mattered in life and in the classroom, he was surprisingly modern in his instructional reach despite, or perhaps because of, the lack of a teaching credential. Current educational theorists would no doubt applaud his determination to fit the curriculum to the children he taught, his dexterity and patience in drawing out youngsters' innate abilities, and the ease with which he combined academic study with the practicalities of real life. Decades before educators began talking about "educating the whole child," or even "character education," Walsh was concerned with such things. He shucked aside parts of the provincial curriculum emphasizing content mastery, drill and recitation and other elements that commonly comprised the vocabulary of instruction at the time.

Although a classroom amateur, we can see in Walsh's career many of the "progressive" ideas beginning to percolate through the province's educational vanguard in the 1920 s. Although Putman and Weir's 1925 survey of provincial schools had propagated these new ideas about changing the meaning and methods of schooling, they remained alien to the ways most teachers thought about and practiced their work until the late 1940s or early 1950s. Where Walsh obtained his notions about a less formal and more interdisciplinary approach to teaching is unclear. It is more likely that he encountered such ideas from his own reading of fashionable educational texts or journals than from the practices of those around him. Walsh claimed otherwise, however, locating the source of his approach in his own life experiences as well as a system of "trial and much error" occasioned by the challenges of teaching a curriculum foreign in its contents to Aboriginal children and in a language far beyond the grasp of most. ${ }^{113}$ "[I]t may sound. . that my ideas were fully developed when I arrived," he later confided about his days at Inkameep, "nothing could be further from the truth." 114

While never explicitly stated, Walsh's actions suggest he did not see schools as institutions with fixed educational agendas, notably the transmission of knowledge across generations, or instruments of colonization directed toward socializing children of minorities into values and norms of the larger society. Walsh's aversion to authoritarian structures is, perhaps, not surprising given his own upbringing and non-directive nature. Accordingly, during his watch, the school at Six Mile Creek grew to become a community centre offering health and other social services. At Inkameep, the school evolved as a cultural agency, or a museum for living, where Aboriginal children were free to discover and express traditions and stories of their own people without a strict timetable. ${ }^{15}$ Contemporary educators, still bedeviled by difficulties in Aboriginal and minority schooling, may well wish to reflect on the efficacy of Walsh's respect for contextual factors surrounding school activities, the unadorned humanism that defined his general behaviour, and the fundamental appreciation he demonstrated for the cul- 
ture and values of others. Alas, Walsh's story likewise reminds us that teachers' accomplishments, however meaningful in their own time, are, sadly, fragile and short-lived. Following his departure, Inkameep's abrupt return to the chaos of earlier days testifies to the impermanence of Walsh's legacy.

Beyond the world of teaching, Walsh's experiences at Six Mile Creek and Inkameep are important for another reason. They provide new and interesting angles of vision into the operations of Indian day schools, a topic overlooked in the large and emerging literature on residential schools. Through his teaching appointments and the relationships he maintained with agencies of church and state, we are able to glimpse into the bureaucratic system that governed the schooling of many Aboriginal children, the suffocating sense of cultural superiority this system embodied, its lack of accountability to those it allegedly served and the general myopia of DIA and religious authorities to the harsh realities of life on the reserves. In official correspondence and reports on Walsh's work, the indifference of officialdom to the social and educational plight of Aboriginal children is manifest, as is the disinterest of government and church authorities in the competence of teachers they recruited and the conditions in which these teachers lived and worked. Before and after Walsh, the quality of instruction at these two day schools was at best haphazard and, all too frequently, placed in the hands of failed and troubled individuals likely incapable of securing employment elsewhere. Within such a context, Walsh's decade-long tenure as a teacher constitutes but a brief moment of illumination in an otherwise dark landscape.

Walsh's story likewise serves to remind us that the history of Aboriginal education in British Columbia is more than a simple morality play featuring oppressors and the oppressed. Walsh's success as a promoter of Aboriginal arts and crafts at Inkameep during the 1930s brought him into a wider cultural world and into contact with a growing number of people in the arts, as well as academic and public life, who were beginning to challenge government's social and educational policies for Aboriginal peoples. Leading this group was a small but dedicated intelligentsia in Victoria that coalesced around Aboriginal advocate, Alice Ravenhill, to form the Society for the Furtherance of British Columbia Indian Arts and Crafts. Eventually, the Society came to include farmers, ranchers, and educators in the Okanagan Valley, as well as figures of national cultural prominence, who resisted the status quo in Indian affairs.

For more than two decades, the Society and its friends lobbied quietly for greater public recognition of rights for Aboriginal peoples, the protection of their cultural heritage and consideration of their place within a national identity that was not yet defined. Walsh's work was galvanic in this movement. In a 1941 article entitled, "They too have something to offer," a writer for The Calgary Herald cogently observed the new consciousness that Walsh was helping to create:

In these days when we are learning to place new values upon the things we have so long accepted without question, when we are talking about the 'new order' to come after the war, we may be neglecting the essential basis of a true Canadian expression of the individual. Out in the Okanagan, at a little Indian day school on the Inkameep reservation Anthony Walsh is doing that very thing. ${ }^{116}$ 
Although not altogether effective in their attempts to change the status quo in the short term, Walsh and the Society were no doubt effective in the long term in their efforts to sensitize British Columbians and other Canadians to the value of Aboriginal art and culture in national life and to the marginalization of Aboriginal society that government policies had historically fostered. Only in the 1970s and 1980s would the effects of their efforts become more evident as public interest in Aboriginal art was renewed and as Aboriginal peoples established their own place on the national political stage, including a much greater degree of control over their own education. ${ }^{117}$

\section{Notes}

1 See, for example: Celia Haig-Brown, Resistance and Renewal: Surviving the Indian Residential School (Vancouver: Arsenal Pulp Press, 1988); Agnes Grant, No End of Grief: Indian Residential Schools in Canada (Winnipeg: Pemmican Publications, 1996); Suzanne Fournier and Ernie Crey, Stolen From Our Embrace: The Abduction of First Nations Children and the Restoration of Aboriginal Communities (Vancouver: Douglas and McIntyre, 1997); and J.S. Milloy, A National Crime: The Canadian Government and the Residential School System, 1879-1986 (Winnipeg: University of Manitoba, 1999).

2 This paper is drawn from a larger study on the life of Tony Walsh. See: Lisa Marie Smith, Portrait of a Teacher: Anthony Walsh and the Inkameep Indian Day School, 1932-1942 (Unpublished Master of Arts thesis: University of Victoria, 2004).

3 Cornell University Jean Webber, Collection \#4602, Series G, Box 145, Division of Rare and Manuscript Collections, "Dr. Anthony Walsh: The Gentle Revolutionary," in Okanagan Historical Society Forty-First Report (November 1, 1977), 130. A letter from Walsh to Father Daniel Berrigan, Cornell University, dated June 20, 1972, confirms he was baptized at the church St. Antoine de Padoue in Paris.

4 British Columbia Archives (hereafter BCA), Add.MSS box 1, file 13, "Become Healers of Hurt, Wounded: Warm Welcome for Dr. Anthony Walsh,” Oliver Chronicle, April 7, 1976.

5 Jean Webber, "Dr. Anthony Walsh: The Gentle Revolutionary," in Okanagan Historical Society Forty-First Report (November 1, 1977), 130.

6 Stephen Hagarty, "Gentle Man Who Challenged Others," Compass (March/April 1995), 39.

7 Edna Kells, "Ancient Culture Lives For B.C. Indian Children," Family Herald and Weekly Star, October 2, 1940.

8 John Buell, "The Man Who Was Poor: Tony Walsh, 1899-1994," The Canadian Catholic Review (November 1994), 15-19.

9 Jean Webber, "Beloved Teacher Dies," Osoyoos Times, Wednesday August 10, 1994, 16.

10 National Archives of Canada (hereafter NAC), RG-10, vol. 6406, file 835-1, part 3, 1, Indian Agent James Coleman to the Assistant Deputy and Secretary, DIA, February 17, 1932.

11 E. Brian Titley, "Indian Industrial Schools in Western Canada," in Nancy M. Sheehan, J. Donald Wilson and David C. Jones eds., Schools in the West: Essays in Canadian Educational History (Calgary: Detselig, 1986), 134.

12 Although less powerful institutions of socialization than residential schools, historian Jean Barman argues that day schools likewise served to marginalize Native youth from their own communities as well as mainstream society. See Jean Barman, "Schooled for Inequality: The Education of British Columbia Aboriginal Children," in Children, Teachers and Schools in the History of British Columbia, ed. Jean Barman, Neil Sutherland, and J.D. Wilson (Calgary: Detselig Enterprises Ltd., 1995), 57. 
13 (NAC), RG -10 vol. 6012, file 1-1-5bc part 1, Harold W. McGill, Department of Indian Affairs (hereafter DIA) Memorandum, November 25, 1942. This memorandum shows that support for day schools as institutions for educational instruction slowly grew within the Dominion Government's bureaucracy as their numbers increased.

14 DIA, Annual Report 1930-1931, 12.

15 In 1932, on average, 1,864 residential school students and 825 day-school students were attending such institutions in British Columbia.

16 At the time of Walsh's first teaching appointment, most day school teachers in the province, 30 out of 46 to be precise, were female. At this time, $79 \%$ of rural $\mathrm{BC}$ teachers were female.

See Thomas Fleming and Carolyn Smyly, "The Diary of Mary Williams: A Cameo of Rural Schooling in British Columbia, 1922-1924," in Jean Barman, Neil Sutherland, and J.D. Wilson, Children, Teachers and Schools in British Columbia (Calgary, Alberta: Detselig, 1995), 259-284.

17 John Buell, Traveling Light: The Way and the Life of Tony Walsh (Toronto: Novalis, 2004), 30.

18 Schoolmistress Mary Carolina Williams was typical in age and experience of the young women who staffed rural and remote schools. For a discussion of her career and the context of rural schooling in British Columbia in the 1920s, see: Fleming and Smyly, "The Diary of Mary Williams," 259-284.

19 Circumstances explicitly noted by Titley, "Indian Industrial Schools," 134.

20 NAC, RG-10 vol. 6405, file 833-1, part 1, c8744.

21 Ibid.

22 Marsden spent his summer at St. Paul's Hospital before going to the Mayo Clinic in Rochester for treatment of his "disease of the bladder." Altogether, Marsden served the DIA as a teacher for 12 years. Prior to this, he was an architect.

23 NAC, RG-10 vol. 6405, file 833-1, part 1c-8744, F.J.C. Ball, to the Assistant Deputy and Secretary DIA, October 16, 1929.

24 University of Victoria Special Collections, Walsh's "Memoirs" (catalogued by Stephen Hagarty), 18.

25 Ibid., 13.

26 Ibid. Walsh's role as "acting chief" raises important questions that are certainly worthy of future research. In particular, it would be of great interest to understand the nature of the Inkameep reserve and how it was declared Roman Catholic, how its members were able to resist government pressures to send their children to residential schools and how and why some of the parents disapproved of Walsh's techniques to incorporate Aboriginal art work into daily lessons. Although Native people have generally been portrayed as victims of white settlers missionary activities, Susan Gray and others have recently noted that some Native groups were in control of making their own choices, and, therefore, "the history of Indian/missionary encounter must be seen as interactive - as meetings between different systems of meaning." See S. Gray, "The Ojibway world view and encounters with Christianity along the Berens River, 1875-1940" (PhD. diss., University of Manitoba, 1996), 6. See also C. Haig-Brown and D. Nock, With Good Intentions (Vancouver: UBC Press, 2006).

27 Ibid.

28 NAC, RG-10, vol. 64-65, file 834-1, part 1, Indian Inspector Barry's report of a visit to the Osoyoos Indian Day School on January 24, 1933.

29 NAC, RG-10, vol. 6405, file 833-1, part 1, Indian Agent James Coleman to Superintendent of Indian Education R.F. Ferrier.

30 British Columbia, Annual Report of the Public Schools, 1932-1933, M40.

31 NAC, RG-10 vol. 6405, file 832-11, part 1.

32 NAC, RG-10, vol. 6406, file 835-1, part 3, 1, Indian Agent James Coleman to the Assistant Deputy and Secretary, DIA, February 17, 1932. 
33 Ibid.

34 NAC, RG-10 vol. 6405, file 833-1, part 1, A.F. Mackenzie to Assistant Indian Commissioner C.C. Perry, August 10, 1932.

35 NAC, RG-10, vol. 6405, file 834-1, part 1, Indian Agent Robert Brown to Deputy Superintendent General D.C. Scott, November 5, 1914.

36 Walsh, "Memoirs," 20.

37 Ibid.

38 NAC, RG-10, vol. 6405, file 833-1, part 1, B.C. Inspector of Indian Agencies A. McGraw, to the DIA.

39 Ibid.

40 NAC, RG-10, vol. 6405, file 834-1, part 1, Indian Agent Robert Brown to the Secretary, DIA, October 16, 1916.

41 NAC, RG-10, vol. 6405, file 834-1, part 1, Indian Agent F.C. Ball to Department of Indian Affairs, July 10, 1919.

42 Walsh, "Memoirs," 20.

43 NAC, RG-10, vol. 6405, file 834-1, part 1, November 27, 1919.

44 Buell, Traveling Light, 35.

45 BCA, Add.MSS 1116, vol. 1, file 17, Society for the Furtherance of Indian Arts and Crafts, "Memorandum: Reasons for Starting the Association."

46 Buell, Traveling Light, 31. From 1931-32, there were 8,950 students enrolled in Indian Day schools across Canada. Average attendance was 5,707 (or 64 per cent). In this same year, 316 teachers were employed in day schools across the nation, with 52 in the province of British Columbia. Department of Indian Affairs, Annual Reports 1864-1990, www.collectionscanada.ca/indianaffairs/020010-101.01-3.php.

47 Jean Webber "Beloved Teacher Dies," Osoyoos Times, Wednesday August 10, 1994, 16.

48 See, for example: Thomas Fleming, Carolyn Smyly and Julie White, "Beyond Hope and Past Redemption," in Thomas Fleming, School Leadership: The British Columbia Experience, 1872-1995 (Mill Bay, B.C.: Bendall Books, 2001), 101-132; J. Donald Wilson, "The Vision of Ordinary Participants: Teachers' Views of Rural Schooling in British Columbia in the 1920s" in Patricia Roy, ed., A History of British Columbia: Selected Readings (Copp Clark Pitman: Mississauga, Ontario, 1989), 239-355; and J. Donald Wilson and Paul J. Stortz, "May the Lord Have Mercy on You: The Rural School Problem in British Columbia in the 1920s," BC Studies (Winter 1988-1989).

49 Buell, Traveling Light, 30.

50 Miller, Alone for Others, (23) recounted an interview with Jane Stalkia.

51 Anthony Walsh, "Earliest Canadians and their Modern Country," The Ensign, September 3, 1949, 16.

52 Walsh, "Memoirs," 28.

53 Ibid.

54 Ibid., 12.

55 As Walsh later recalled (Ibid., 30): "The stimulus provided by the rock paintings was a definite breakthrough."

56 For the past several years, University of Victoria anthropologist Andrea Walsh has been studying the artwork of the children of Inkameep. In addition to an on-line virtual gallery of the children's artwork, Walsh has presented several papers on the topic. See for example, "No Small Work: Anthropology, Art, and Children." Paper read at the Canadian Anthropology Society meetings, May 09, 2003, Halifax, Nova Scotia. Retrieved June 6, 2006 from www.virtualmuseum.ca/Exhibitions/Inkameep/english/story/index.php.

57 Buell, Traveling Light, 38.

58 BCA, Add.MSS 2629.

59 Miller, Alone For Others, 41. 
60 Walsh, "Memoirs," 34.

61 BCA, Add.MSS 1116, box 3, Stella Gysin, "Indian Art," The Canadian League, (May 1939).

62 Walsh, "Memoirs," 34.

63 Walsh cited in Buell, Traveling Light, 40.

64 Ibid.

65 NAC, RG-10, vol. 6405, file 833-1, part 1, Indian Agent James Coleman to Superintendent of Indian Education Russell Ferrier.

66 Martha Ludley Hall, "Closing Day at Inkameep School," Education Digest (December 1939), 18.

67 Mary Elizabeth Coleman. "What We Are Reading," The B.C. Teacher (November 1941), vol. 21.

68 BCA, Add.MSS 1116, box 3, Stella Gysin, "Indian Art," The Canadian League (May 1939).

69 Walsh, "Memoirs," 56.

70 Ibid., 70.

71 BCA, Add.MSS 2629, box 1, file 12 "Inkameep and the Drama."

72 Walsh, "Memoirs," 60-61.

73 Ibid., 59.

74 BCA Add.MSS 1116, box 3, Edna Kells, "Ancient Culture Lives For B.C. Indian Children," Family Herald and Weekly Star, October 2, 1940.

75 BCA, Add.MSS 1116, box 3, "Indian Group of Inkameep Cup Winners," The Penticton Herald, Thursday April 25, 1940.

76 BCA, Add.MSS 116, box 3, "Review: Tale of the Nativity," The School: Elementary Edition (December 1940), University of Toronto, 3.

77 UBC Special Collections, Alice Ravenhill Papers 1939-1951, box 1, Alice Ravenhill to Walsh, February 27, 1943.

78 BCA Add.MSS 1116, box 3, "Nativity Tale Appreciated by Educators," The Daily Colonist, Tuesday, December 3, 1940.

79 BCA, MSS 1116, box 1, file 4, September 18, 1941.

80 Central to the manufacture of Walsh's newfound public status was Victoria's Alice Ravenhill and the Society for the Furtherance of British Columbia Indian Arts and Crafts. Ravenhill, the most influential figure associated with Walsh's work at Inkameep, was a former Cambridge lecturer and a self-taught authority on British Columbia Native art. Impressed with Walsh's successes at Inkameep and eager to offer support, Ravenhill introduced Walsh to a small group of culturally conscious Victorians. By 1939, this group and others had formed the first chapter of an association known as the "Society for the Furtherance of British Columbia Indian Arts and Crafts," followed two years later by an Okanagan branch, that also included Aboriginal members, headed by Walsh's longtime friends, Albert and Daisy Millar. Using the Society as a platform, Ravenhill constructed a national network of artists, educators and anthropologists to promote Walsh's work and to lobby for changes to the Indian Act.

81 Ibid. Walsh's pedagogy was clearly ahead of its time. In 1990, Miller and Seller categorized three contemporary curricular models. The first of these is the transmission model in which traditional, factual knowledge is transmitted to learners through rote-type learning methods. In the transactional model, individual learners are capable of intelligent problem solving within social and democratic contexts. The transformational curricular model empowers learners to make personal and social change. Walsh's "cultural revival" pedagogy most closely approximates the third (transformational) position. Interestingly, contemporary curriculum theorists argue that this position is the most difficult position for contemporary educators to implement.

82 Karl Jaspers, Tragedy is Not Enough (Boston: Beacon Press, 1969). 
83 "Seek Recognition of Indian Contribution to Canadian Culture: Teacher at Indian School Gives Unique Program at Women's Canadian Club," Vancouver Province, September 18, 1941.

84 NAC, RG-10, vol. 6405, file 834-1, part 2, Walsh to Indian Agent A.H. Barber, December 1, 1942.

85 Miller, Alone for Others, 67.

86 UBC Special Collections, Alice Ravenhill Papers 1939-1951, box 1, December 19, 1942.

87 NAC, RG-10, vol. 6405, file 834-1, part 2, Indian Agent James Coleman to D.M. MacKay Indian Commissioner for B.C., April 24, 1944.

88 Ibid.

89 NAC, RG-10, vol. 6405, file 834-1, part 1, Indian Agent James Coleman to the Secretary of Indian Affairs, Ottawa, June 12, 1934.

90 Miller, Alone for Others, 73-74.

91 Ibid.

92 Ibid., 68.

93 Walsh, "Memoirs," 67.

94 Ibid.

95 Ibid.

96 Ibid.

97 Ibid., 42-43.

98 NAC, RG-10, vol. 6405, file 834-1, part 2, Indian Agent A.H. Barber, Report on Okanagan Indian Agency for the Month of September 1943.

99 NAC, RG-10, vol. 6405, file 834-1, part 2, Indian Agent A.H. Barber, Report to the Department of Indian Affairs on Okanagan Indian Agency for September 1943.

100 NAC, RG-10, vol. 6405, file 834-1, part 2, Indian Agent A.H. Barber to Major D.M. MacKay, Indian Commissioner for B.C., January 17, 1944.

101 NAC, RG-10, vol. 6405, file 834-1, part 2, Indian Commissioner for B.C. D.M. MacKay to Indian Agent A.H. Barber, January 20, 1944.

102 NAC, RG-10, vol. 6405, file 834-1, part 2, Superintendent of Welfare and Training R.A. Hoey to Indian Commissioner for B.C Major D.M. MacKay, April 13, 1944.

103 Irene Baptiste cited in Miller, Alone for Others, 16.

104 Ibid.

105 BCA, Add.MSS 1116, box 2, file 4, A. Dalrymple, "On the Farm: B.C. Teacher Returns from Study in South,” The Vancouver Daily Province, Saturday, October 4, 1947.

106 Buell, Traveling Light, 53.

107 UBC Special Collections, Alice Ravenhill Papers 1939-1951, "Addressed to the Royal Commission of Senators and Members of the House of Commons Appointed to Inquire into all Phases of the Affairs of Canadian Indians in May and October, 1946 (Chiefly Educational) are Submitted in the Hope of Contributing to the Rehabilitation of the Indians of British Columbia."

108 BCA, MSS 2629, Helen Baird to Walsh, March 13, 1951.

109 Miller, Alone for Others, 73.

110 BCA, Add.MSS 2629, vol. 1, box 1, Elizabeth Prangnell.

111 Collection of Sister Rose Dorothy, Walsh to Sister Audrey Beauvais, October 16, 1977.

112 Miller, Alone for Others, 70.

113 Walsh, "Memoirs," 29.

114 Ibid.

115 Ibid., 75.

116 "He Works to Restore Indian Pride of Race," The Calgary Herald, Tuesday, September 8, 1942.

117 "National Indian Brotherhood, Indian Control of Indian Education, Ottawa: N.I.B., 1972." 